\title{
Doing Business using Cryptocurrency in Malaysia
}

\author{
Ahmad Shauqi Zubir, Nur Aishah Awi, Azwadi Ali, Safiek Mokhlis, Farizah Sulong
}

\begin{abstract}
As the society is becoming more digitised day by day, we are being constantly introduced with advanced smart technologies that transpire changes in our lives. The blockchain technology and cryptocurrencies came in at the appropriate time which has provided pathways and security for many vulnerable internet-connected devices as the technology uses distributed verification of transactions. Due to their unique features, cryptocurrencies carry value on their own and now can be used for trading and transactions. In many established markets, transactions and trading in cryptocurencies have been growing and many have seen them as potential assets and investment option. Nevertheless, in many other countries, cryptocurrencies are not very popular and due to lack of awareness, many of their citizens are yet to own any cryptocurrencies. This study assessed the awareness of cryptocurrencies among selected Malaysian public and tested certain determinants and found almost three quarter of the respondents were aware of them but none is owning even one digital currency. Among the determinants, age group, ethnicity and occupation status were found to have influenced respondents' awareness about cryptocurrencies. If it is an interest of the government to promote the use of cryptocurrencies, necessary exposure campaigns as well as guarantee of control and security should be made a priority.

Key words: cryptocurrency, financial awareness, online payments, financial products, financial services, financial regulations, Bitcoin.
\end{abstract}

\section{INTRODUCTION}

The Central Bank of Malaysia (bernama.com, 2017) stresses that they are aware that cryptocurrency will be common shortly, as suggested in various media. Because of that, the Central Bank of Malaysia has developed a new regulatory structure specifically for that type of currency. At the same time, they are seeking public inputs to be considered in the structure. So far, Malaysian authorities do not officially prohibit the trading of cryptocurrency, but, at the same time, they are continuously monitoring the development of the cryptocurrency to protect the public interest. Also, certain regulations regarding cryptocurrency have been amended for that purpose, at the time of this writing (Securities Commission Malaysia, 2019).

Revised Manuscript Received on May 15, 2020.

* Correspondence Author

Dr. Ahmad Shauqi Bin Haji Mohamad Zubir*, Finance Lecturer, School of Business and Maritime Management, Universiti Malaysia. Email: shauqi@umt.edu.my

Dr. Nur Aishah, Lecturer of Management (Marketing) Programme, School of Maritime Business and Management, Universiti Malaysia Email: nuraishah@umt.edu.my

Dr. Azwadi Ali, Associate Professor, School of Maritime Business and Management, Universiti Malaysia Terengganu. E-mail: azwadi@umt.edu.my

Dr. Safiek Mokhlis, Associate Professor, obtained his BBA and MSc degrees from University Putra Malaysia, E-mail: safiek@umt.edu.my

Email: farizah.sulong@umt.edu.my

Dr. Farizah Sulong, Lecturer, Tutor under the School of Maritime Business and Management, University Malaysia Terengganu. E-mail: farizah.sulong@umt.edu.my

(C) The Authors. Published by Blue Eyes Intelligence Engineering and Sciences Publication (BEIESP). This is an open access article under the CC BY-NC-ND license (http://creativecommons.org/licenses/by-nc-nd/4.0/)
The trading and transaction of cryptocurrency have gained popularity due to many factors as reported not only in mainstream media but also in academic articles. Blau (2017), for example, stresses that cryptocurrencies are popular to the dealers and buyers because they have lower transaction fees compared to other types of payments like credit cards. Also, cryptocurrency transactions are private and are conducted anonymously based on peer-to-peer transactions. Furthermore, cryptocurrencies can act as speculative assets. In addition, cryptocurrencies also attract people as they can be acquired via a mining process (Hayes, 2017, among others). Lastly, Bouri et al. (2017) showed that cryptocurrencies like Bitcoin could be used to hedge against uncertainty in the global market. Nevertheless, so far, no research has been conducted among Malaysians, about whether they use cryptocurrencies or are even aware of such instruments. Financial awareness includes familiarity and understanding of financial products (Acquah-Sam and Salami, 2013). Financial researchers have underlined the benefits of awareness (Fraczek, 2014, among others). Financial awareness would benefit Malaysian citizens and the Malaysian financial system and economy. Financial awareness would lead to good financial decisions, escalate the development of financial responsibilities and rights, and lead to a better understanding and managing financial needs. Thus, financial awareness plays a crucial role in the financial planning of individuals at the micro-level and of the nation at the macro-level (Shobha and Shalini, 2015). It is said that any unawareness about the available financial products, their features, and the subsequent inability of those products could considerably impact financial planning. Based on these premises, this study was undertaken to examine the awareness of the Malaysians on cryptocurrencies and outcomes. Aggarwal et al. (2012) emphasised that appreciating the relationship between financial knowledge and issues of an individual, matched with the corresponding characteristics, is becoming gradually recognised as an essential field in the financial arena. Furthermore, grasping the developments in alternative financial transactions and trading methods is essential for any central bank as the central bank is commonly the sole issuer of banknotes, so that it could position and use its functions efficiently (Arango et al., 2012; Fung et al., 2015). Further, Bernanke (2011) suggests that financial awareness information should be continuously updated as financial services and products evolve from time to time while simultaneously, the financial needs and circumstances of people also change. Not only that, financial awareness information serves as a basis to measure the vulnerability of one's financial position. In the Malaysian case, Nga et al. (2010) found that Malaysian youth lack financial awareness, and this situation is not favourable to the development of a country. 


\section{Doing Business using Cryptocurrency in Malaysia}

Likewise, the low level of financial awareness among youth in the United Kingdom and the United States will lead them into a debt trap, bankruptcy, and financial difficulties during their retirement (Marriott, 2007; Dale and Bevill, 2007; Hoffman et al., 2008; Perry, 2008). Therefore, findings from this study would provide valuable inputs to the financial regulators in Malaysia in formulating policies, rules, and regulations regarding cryptocurrency. This study addresses the following research questions:

1. Are Malaysians aware of the existence of cryptocurrency as a financial product?

2. How do demographic factors (gender, age, ethnicity, education, occupation, and residencies) influence the awareness of Malaysians of cryptocurrency?

\section{LITERATURE REVIEW}

Yussof and Al-Harthy (2018) opined that money is anything worthy of general acceptance as a medium of financial exchange or anything that is considered as legal tender, either to pay a debt, to perform the accounting procedures and to store wealth. The inception of cryptocurrency could lead to several problems. Among them is the scraping away of confidence in state-issued money state-issued money, especially in online and cross-border could face a difficult task in monitoring financial and economic activities to enforce related laws in finance and maintain financial stability country. Cryptocurrencies are being distributed globally at a fast pace because not only the media who significantly popularise them, but also capital (Glaser et al., 2014). As a consequence, this has created a consumerism. The previous literature on the cryptocurrency were initially dominated by studies on the safety, ethical, and legal aspects of cryptocurrency, although recent literature has started examining cryptocurrency from an economic viewpoint. As Urquhart (2017) noted, cryptocurrency, especially Bitcoin, has received substantial attention from many parties. Katsiampa (2017) found that Bitcoin was first in the cryptocurrency's ranking of popularity and more than $40 \%$ of the approximated cryptocurrency's valuation is in Bitcoin. Bitcoin's value is also reported to be higher than the value of gold, or the value of a portfolio of currencies. It is also found that the minimum volatility of Bitcoin's monthly value is less than the maximum volatility of the gold's monthly volatility or the portfolio of currencies in that sense. Cryptocurrency awareness is said to have a strong relationship with financial awareness (Henry et al., 2017). This is because cryptocurrency is one of the financial products that are offered not only in financial markets by financial service providers but also by other parties in other markets, especially in marketing, retailing and computer science. This is because of the nature of the cryptocurrency itself, which is decentralised and usually operated in a peer-to-peer system (Buterin, 2018). Cryptocurrency awareness can be measured in the sense of whether a respondent has any knowledge of such a product, not necessarily by the direct involvement of the respondents in the usage of cryptocurrency. That is, awareness is defined as the ability to recognise or notice something that people knows of. In among consumers as cryptocurrency could substitute for financial transactions. Furthermore, financial regulators investors, financial intermediaries, researchers, and others new dimension of risks and analyses in finance and

other words, it can also be defined as being informed of something (Bhattacharjee et al., 2017). OECD (2005) surveyed financial awareness and found that, although new financial products are being offered in markets, people might opt not to utilise them, although they are aware of the offering. Similar to that, West (2012) found that financially aware people might not visibly act or be physically involved in the financial products or services of which they are aware. Further, financial awareness also relates to financial matters, especially in the area of personal finance, if the respondents comprise individuals (Thilakam, 2012). Cryptocurrency is mainly targeted to individuals as it uses a decentralised regulation, works on a peer-to-peer system, and does not involve any interference by financial intermediaries (Nakamoto, 2009). These features would pose a disadvantage to any company to be directly involved in cryptocurrency as this involvement would oppose existing laws and regulations, especially in financial reporting and auditing. So far, many countries in the world have not incorporated the regulation of the use of cryptocurrency into their business laws yet, including Malaysia. Henry et al. (2017) studied cryptocurrency awareness among consumers among Canadians. They found that, although the majority of Canadians have heard of cryptocurrency, only a small percentage of them own or have ever used or owned one. In the United States, Schuh and Shy (2016) found that only around $50 \%$ of the US population was aware of cryptocurrency. The inadequate and insufficient dissemination of information was mostly due to the limited distribution of cryptocurrency in the United States. They also found that people who were aware of the cryptocurrency were still reluctant to use cryptocurrency as many people perceived it as a type of investment instrument rather than an alternative method of payment. Polasik et al. (2015) examined the use of Bitcoin in the United States, Germany, the United Kingdom, France, and Canada. They found that many new companies that were in the start-up stage used Bitcoin as one of their money transaction methods. The reason for this is that Bitcoin is used as a marketing strategy to gain quick publicity for those companies by offering something that can be considered new and advanced compared to other existing companies. The customers, on the other hand, were driven by their knowledge level in cryptocurrency about whether they would be involved in cryptocurrency transactions. Also, Bitcoin is found to be less popular than PayPal in the type of online payment that was used by their respondent sample as PayPal is considered as established, common, and less risky compared to Bitcoin. Bitcoin is also found to be significantly associated with the black economy, especially with money laundering and tax avoidance. These characteristics of cryptocurrency users should be further examined to augment the existence of such technology without sacrificing the stability and regulations in finance. However, as Tsanidis et al. (2015) noted, studies on the characteristics of cryptocurrency users and the use of cryptocurrency were limited although knowledge of these is essential based on the cryptocurrency's development nowadays, especially the borderless character of cryptocurrency. 
Bitcoin, for example, should be attractive to most of the people when it comes to global transaction fees as it is cheaper compared to credit cards. Further, Tsanidis et al. (2015) found that the majority of Greek residents were aware of Bitcoin, but only a small portion of them have ever used it for payment purposes. Nevertheless, the majority of them would consider using Bitcoin in the future. For now, only a minority of them trust Bitcoin as a payment method. Notably, Greeks were also found to use the Internet less compared to their European counterparts.

\section{III.HYPOTHESES DEVELOPMENT}

\section{Gender}

The first variable to be used in describing the cryptocurrency awareness is gender. Studies by Boyd et al. (2014) and Haque (2010) found that differences exist in choosing financial products and services based on certain embedded characteristics like gender. Likewise, the knowledge of financial products and concepts differ between males and females, as Haque (2010), Nga et al. (2010) and Worthington (2006) reported. This can be further described by the fact that women are more financially vulnerable than men, as can be seen from the number of financial scam cases involving women as victims, the lower willingness to acquire financial knowledge and skills between men and women (Chen and Volpe, 2002) and the lower confidence in making financial decisions of women compared to men (Barber and Odean, 2001). Further, Lusardi and Mitchell (2011) found that men are more likely to give correct answers than women and women have less tendency to admit that they do not know the correct answer when taking a financial survey. The findings of Banumathy and Azhagaiah (2016) and Bhushan and Medury (2013) may offer insights into this situation. The difference between financial awareness/literacy between males and females may be associated with the level of education rather than gender itself. Also, women are found to be less passionate in acquiring financial knowledge and skills compared to men (Worthington, 2006), although they are receptive to the education regarding financial matters (Clark et al., 2006). The risk preference in finance may provide an answer to the less passionate behaviour of women in acquiring financial knowledge and skills (Dellande and Saporoschenko, 2004). Henry et al. (2017) found that awareness of Bitcoin is significantly associated with gender in Canada. That is, men are found to be more aware of Bitcoin than women, which similar to Schuh and Shy's (2016) findings of the US population. Hence, the first hypothesis is:

H1. There is a significant difference between genders regarding cryptocurrency awareness.

\section{Age}

Previous research has shown that age has a significant effect on knowledge and affiliation regarding financial products and services. For example, Awan and Bukhari (2011) found that older generations aged 50 and above have greater knowledge about Islamic financial services than younger generations. At the same time, Ahmad et al. (2011) found that younger generations are more attracted to financial products or services that are convenient to them and also have a good track record, rather than just technology advancement embedded in the financial services. Loo (2010) found a difference in financial products and services perception between baby boomers and Generation X. Concerning financial awareness, the findings have been mixed. Maruthu and Benjamin (2010) found that young investors showed greater awareness compared to their older counterparts. In contrast, Shobana and Jayalakshmi (2010) found that older generations (above 50 years old) had a greater level of financial awareness than the younger generations. The OECD (2016) found that middle-age generations had a greater level of financial literacy/awareness compared to the older and younger generations. Finke et al. (2011) said that older generations tend to show lower financial awareness due to the decrease in cognitive capability among them while Dellande and Saporoschenko (2004) mentioned that as people grow older, they are more likely to be more conventional and unfavourable to any financial risk. Recently, Tsanidis et al. (2015) found that Bitcoin usage was significantly different between age groups in Greece. Hence, the second hypothesis is:

H2. There is a significant difference between age groups regarding cryptocurrency awareness.

\section{Ethnicity}

In Malaysia, ethnic Malays, Chinese, and Indians differ significantly in choosing financial services or products (Haque, 2010). This is because the objectives of these ethnicities towards financial services and products differ (See Sabri et al., 2012 and Clercq, 2009). The differences in financial objectives are due to the principles and lifestyles of the ethnics themselves. In addition, concerning financial awareness, Jeyaram and Mustapha (2015) found that Chinese scored higher than the ethnic Malays and Indians. Not only that, more Chinese people in Malaysia are found to be financially literate than other ethnics (Kimiyaghalam and Yap, 2017; Loke, 2015), including doing better in debt management compared to other ethnicities (Jariah et al., 2017). The Indians are the most financially illiterate of all the other ethnics in Malaysia (Kimiyaghalam and Yap, 2017). Hence, the third hypothesis is:

H3. There is a significant difference between ethnicity groups regarding cryptocurrency awareness.

\section{Education}

Education plays a significant role in affecting people's choice of certain financial services and products (Al Ajmi et al., 2009; Rashid and Hassan, 2009). For example, people with at least a minimum qualification in tertiary level of education are choosy in selecting financial services compared to other education level groups (Awan and Bukhari, 2011). In terms of financial awareness level, Nga et al. (2010) found that financial awareness significantly differs among education level groups, although only when tested on certain financial services and products. Based on a broader survey, which includes 30 countries, OECD (2016) found that education level has a strong relationship with financial awareness.

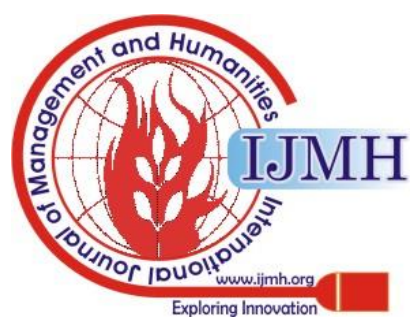




\section{Doing Business using Cryptocurrency in Malaysia}

Not only that, the education level in finance also affects satisfaction in the outcome of making a financial decision (Joo and Grable, 2004; Chen and Volpe, 2002). Educational group has also played a significant role in the awareness of Bitcoin (Henry et al., 2017; Schuh and Shy, 2016; Tsanidis et al., 2015). Hence, the fourth hypothesis is:

H4. There is a significant difference between education groups regarding cryptocurrency awareness.

\section{Occupation}

Working experience also influences financial awareness (Chen and Volpe,1998). Employed persons gather information about financial service providers and choose providers that meet their needs, which are quick to respond and friendly to them (Awan and Bukhari, 2011). Further, Maruthu and Benjamin (2010) found that employed persons, especially the ones involved in business matters, achieved higher financial awareness compared to other occupations. This finding is supported by Shobana and Jayalakshmi (2010). Bhushan and Medury (2013) later found that the higher level of financial awareness among employed persons is due to the type of employment and the operational place of a person. Although employed persons have greater financial awareness than unemployed persons, more employees who are from private sector show greater financial awareness than employees from the public sector. However, according to Henry et al. (2017), unemployed persons are found to be more aware of Bitcoin than their employed counterparts. Hence, the fifth hypothesis is:

H5. There is a significant difference between occupation groups regarding cryptocurrency awareness.

\section{Residency}

OECD (2016) found that large countries affect the level of financial awareness. That is, residency itself is significant in achieving the level of awareness. Also, Bucher-Koenen and Lusardi (2011) and Klapper and Panos (2011) found that the results from certain countries in Eastern Europe indicate that the pattern of financial awareness is significantly different from others. Likewise, Bumcrot et al. (2013) found that residency influenced the variation in financial literacy across states in the United States. This may be explained partly by the economic characteristics, policies, and demographics of each state. Based on similar premises, Polasik et al. (2015) found that residents in the countries with a higher GDP per capita used less cryptocurrency compared to the residents in the countries with lower GDP per capita in their sample. In a more recent study, Morgan and Trinh (2019) found that people who live in urban areas in Vietnam and Cambodia show a greater level of financial literacy compared to people from rural areas. Hence, the sixth hypothesis is:

H6. There is a significant difference between residency groups regarding cryptocurrency awareness.

\section{IV.METHODOLOGY}

The sample for this study comprises Malaysian residents from different regions (North, West Coast, South, East Coast, and East Malaysia). Therefore, cluster sampling was used. This is in line with the suggestion by Che-Ha et al. (2017), Morgan and Trinh (2019) and Bumcrot et al. (2013). Questions for the cryptocurrency awareness survey were taken from Henry et al. (2017), who surveyed Bitcoin awareness among Canadians for the Bank of Canada. Much prior research has used descriptive analysis, especially percentage, and correlation, to measure the financial awareness level (Bhattacharjee et al., 2017). The sample size they used was mostly less than 500, and the financial awareness level was examined by using non-parametric tests. For this study, 400 peoples were surveyed after being randomly selected through social media, emails, and messaging apps. For hypothesis testing, Pearson ChiSquare, Phi, and Cramer's V tests were used. All are nonparametric tests and the use of non-parametric tests in exploring the categorical variables in financial awareness has also been done by prior researchers, for example Henry et al. (2017), Che-Ha et al. (2017), Tsanidis et al. (2015), Thambiah et al. (2011), Khattak and Rehman (2010) and Loo (2010), among others.

\section{V.ANALYSIS AND RESULTS}

\section{Respondent's Demographic Profile}

The demographic background of the respondents can be seen in Table 1. From the total number of 400 respondents, 300 (75\%) were female, while 100 (25\%) were male. As expected, many of them were 18 to 25 years old. This is because this age group is most reachable as the questionnaires were distributed through electronic communications such as social media, emails, and messaging apps. The majority of the respondents were ethnic Malay, followed by Chinese and Indian. The other group of ethnicity includes aborigines from Peninsular and East Malaysia. In terms of education level, $89 \%$ of them had a bachelor's degree, followed by a diploma (5\%), master's degree $(2.75 \%)$, secondary school certificate $(2 \%)$ and doctoral degree (1.25\%). For occupational status, the majority were employed (60.75\%), followed by students (37.5\%) and unemployed (1.75\%). In terms of residency, 43.5\% were from the East Coast of Malaysia (Kelantan, Terengganu, and Pahang), 24.25\% were from the West Coast of Malaysia (Perak, Selangor, Kuala Lumpur, Putrajaya, and Melaka), 14.25\% were from Northern Malaysia (Perlis, Kedah and Pulau Pinang), 13\% were from Southern Malaysia (Negeri Sembilan and Johor) and 5\% were from East Malaysia (Sabah, Labuan, and Sarawak). $97.25 \%$ of the respondents were single while the rest were married (2.5\%) and widowed (0.25\%). 
Table 1: Respondent's Profile

\begin{tabular}{|c|c|c|c|}
\hline Variables & Categories & Total & Percent (\%) \\
\hline \multirow[t]{2}{*}{ Gender } & Female & 300 & 75.00 \\
\hline & Male & 100 & 25.00 \\
\hline \multirow[t]{5}{*}{ Age } & $18-25$ & 356 & 89.00 \\
\hline & $26-35$ & 15 & 3.75 \\
\hline & $36-45$ & 12 & 3.00 \\
\hline & $46-55$ & 10 & 2.50 \\
\hline & Above 55 & 7 & 1.75 \\
\hline \multirow[t]{4}{*}{ Ethnicity } & Malay & 325 & 81.25 \\
\hline & Chinese & 47 & 11.75 \\
\hline & Indian & 22 & 5.50 \\
\hline & Other & 6 & 1.50 \\
\hline \multirow[t]{5}{*}{ Education } & Secondary School & 8 & 2.00 \\
\hline & Diploma & 20 & 5.00 \\
\hline & Degree & 356 & 89.00 \\
\hline & Master & 11 & 2.75 \\
\hline & Doctorate & 5 & 1.25 \\
\hline \multirow[t]{3}{*}{ Occupation } & Student & 150 & 37.50 \\
\hline & Employed & 243 & 60.75 \\
\hline & Unemployed & 7 & 1.75 \\
\hline \multirow[t]{5}{*}{ Residence } & Northern Region & 57 & 14.25 \\
\hline & West Coast Region & 97 & 24.25 \\
\hline & Southern Region & 52 & 13.00 \\
\hline & East Coast Region & 174 & 43.50 \\
\hline & East Malaysia Region & 20 & 5.00 \\
\hline \multirow[t]{3}{*}{ Marital } & Single & 389 & 97.25 \\
\hline & Married & 10 & 2.500 \\
\hline & Widowed & 1 & 0.25 \\
\hline
\end{tabular}

\section{Awareness of Cryptocurrency}

Descriptive statistics for cryptocurrency's awareness can be seen in Table 2. The data were collected using a dichotomous scale (yes or no) for variable heard (Have you heard of cryptocurrency like Bitcoin, Ripple, etc.?), Own (Do you currently have or own any cryptocurrencies like Bitcoin, Ripple, etc.?) and Owned/Used (Have you owned or used a cryptocurrency like Bitcoin, Ripple, etc., but subsequently stopped using it?). For other variables, which are AmountOwn (How many cryptocurrencies like Bitcoin, Ripple, etc.) do you own?), ReasonNotOwn (If no, please state your main reason for not owning any cryptocurrencies like Bitcoin, Ripple, etc.) and PreferredPayment (What is your preferred method of payment for making purchases online?). Multiple-choice answers were given. The results show that the majority have heard of cryptocurrency, but none of them owned any cryptocurrency at the time of the survey. However, a small portion (7\%) answered yes when asked whether they had owned or used cryptocurrency before. When asked the reason for not owning cryptocurrency, the answers given varied. The most frequent response was because they did not know or understand enough about cryptocurrency (40\%). None of them preferred cryptocurrency as a type of online payment.

Table 2: Respondent's Awareness of Cryptocurrency

\begin{tabular}{|l|l|r|r|}
\hline Variables & Categories & Total & Percent (\%) \\
\hline Heard & Yes & 297 & 74.25 \\
\hline & No & 103 & 25.75 \\
\hline Own & Yes & 0 & 0.00 \\
\hline & No & 400 & 100.00 \\
\hline AmountOwn & None & 400 & 100.00 \\
\hline & More than 0 but less than 10 & 0 & 0.00 \\
\hline & 10 to 100 & 0 & 0.00 \\
\hline & More than 100 & 0 & 0.00 \\
\hline Owned/Used & Yes & 28 & 7.00 \\
\hline & No & 372 & 93.00 \\
\hline
\end{tabular}


Doing Business using Cryptocurrency in Malaysia

\begin{tabular}{|c|c|c|c|}
\hline \multirow[t]{8}{*}{ ReasonNotOwn } & $\begin{array}{l}\text { I do not understand/know enough } \\
\text { about the technology }\end{array}$ & 160 & 40.00 \\
\hline & $\begin{array}{l}\text { It is not widely accepted as a } \\
\text { method of payment }\end{array}$ & 73 & 18.25 \\
\hline & $\begin{array}{l}\text { My current payment methods } \\
\text { meet all my needs }\end{array}$ & 37 & 9.25 \\
\hline & $\begin{array}{l}\text { The value of cryptocurrency } \\
\text { (Bitcoin, Ripple, etc.) varies too } \\
\text { much }\end{array}$ & 11 & 2.75 \\
\hline & It is not easy to acquire/use & 18 & 4.500 \\
\hline & $\begin{array}{l}\text { I do not trust a private currency } \\
\text { that is not backed by the central } \\
\text { bank/government }\end{array}$ & 64 & 16.00 \\
\hline & I am concerned about cyber theft & 25 & 6.25 \\
\hline & $\begin{array}{l}\text { I am concerned about a lack of } \\
\text { oversight from regulatory bodies }\end{array}$ & 12 & 3.00 \\
\hline \multirow[t]{4}{*}{ PreferredPayment } & Credit card & 51 & 12.72 \\
\hline & Debit card & 304 & 76.00 \\
\hline & PayPal & 45 & 11.25 \\
\hline & $\begin{array}{l}\text { Cryptocurrency (Bitcoin, Ripple } \\
\text { etc) }\end{array}$ & 0 & 0.00 \\
\hline
\end{tabular}

\section{Hypothesis Testing}

For hypothesis testing purpose, Pearson Chi-Square, Phi, and Cramer's V tests were used. All of them are nonparametric tests, which measure the relationship between two or more categorical variables. Specifically, the Pearson Chi-Square test is used to discover any differences across categorical variables while the Phi and Cramer's V tests are used to determine the strength of association between those categorical variables. The null hypotheses for these tests are that no association/relationship exists between categorical variables. Hence, if the result is significant, the assumption is that an association/ relationship exists between the categorical variables.

The results for hypotheses testing can be seen in Table 3 .

Table 3: Tests on Hypotheses

\begin{tabular}{|l|l|l|l|l|l|l|l|}
\hline Variables & & Heard & Own & $\begin{array}{l}\text { Amount } \\
\text { Own }\end{array}$ & $\begin{array}{l}\text { Owned/ } \\
\text { Used }\end{array}$ & $\begin{array}{l}\text { Reason } \\
\text { NotOwn }\end{array}$ & $\begin{array}{l}\text { Preferred } \\
\text { Payment }\end{array}$ \\
\hline Gender & Chi-Square & 0.21 & - & - & 1.84 & 8.58 & $5.27^{* * *}$ \\
\hline & Phi & -0.02 & - & - & -0.07 & 0.15 & $0.12^{* * *}$ \\
\hline & Cramer's V & 0.02 & - & - & 0.07 & 0.15 & $0.12^{* * *}$ \\
\hline Age & Chi-Square & $10.23^{* *}$ & - & - & 2.43 & 24.17 & 9.83 \\
\hline & Phi & $0.16^{* *}$ & - & - & 0.08 & 0.25 & 0.16 \\
\hline & Cramer's V & $0.16^{* *}$ & - & - & 0.08 & 0.12 & 0.11 \\
\hline Ethnicity & Chi-Square & $17.83^{*}$ & - & - & $8.38^{* *}$ & 25.4 & 10.42 \\
\hline & Phi & $0.21^{*}$ & - & - & $0.15^{* *}$ & 0.25 & 0.16 \\
\hline & Cramer's V & $0.21^{*}$ & - & - & $0.15^{* *}$ & 0.15 & 0.11 \\
\hline Education & Chi-Square & 1.67 & - & - & 3.21 & 37.03 & $13.94^{* * *}$ \\
\hline & Phi & 0.07 & - & - & 0.09 & 0.3 & $0.19^{* * *}$ \\
\hline & Cramer's V & 0.07 & - & - & 0.09 & 0.15 & $0.13^{* * *}$ \\
\hline Occupation & Chi-Square & $8.99^{* *}$ & - & - & 0.61 & 12.91 & $8.68^{* * *}$ \\
\hline & Phi & $0.15^{* *}$ & - & - & 0.04 & 0.18 & $0.15^{* * *}$ \\
\hline & Cramer's V & $0.15^{* *}$ & - & - & 0.04 & 0.13 & $0.1^{* * *}$ \\
\hline Residence & Chi-Square & 1.67 & - & - & $20.7 *$ & 35.59 & 11.28 \\
\hline & Phi & 0.07 & - & - & $0.23^{*}$ & 0.3 & 0.17 \\
\hline & Cramer's V & 0.07 & - & - & $0.23^{*}$ & 0.15 & 0.12 \\
\hline
\end{tabular}

Note: *significant at $0.01, * *$ significant at 0.05 , and ${ }^{* * *}$ significant at 0.1 .

Based on the results, significant differences in cryptocurrency's awareness, measured by whether they have ever heard about cryptocurrency, exists in age groups, ethnic groups, and occupation status groups. Hence, the results show that age, ethnicity, and occupation affect the awareness of cryptocurrency in Malaysia. In terms of whether they have ever used or owned cryptocurrency, 
Hypothesis tests could not be done to test the differences between categorical variables on whether they do own cryptocurrency and the amount of cryptocurrency they own as all respondents answered no and none for those questions, respectively.

Lastly, although none of them chose cryptocurrency as their preferred online payment, differences do exist between gender, education, and occupation status groups for that question. This means that gender, education, and occupation status play a significant role in choosing between credit card, debit card, and PayPal as an online payment method.

\section{VI.DISCUSSION AND CONCLUSION}

The objective of this study was to examine the level of awareness and usage of cryptocurrency in Malaysia based on demographic profiles such as gender, age, ethnicity, education, occupation, and residency. The results showed that age, ethnicity, and occupation affect the awareness of cryptocurrency. These findings indicate that more emphasis should be given to age groups, especially older peoples, as they are less exposed to the current development in information and communication technology compared to the younger generations. Also, prior studies have proven that age affects the selection of financial services and products because the age factor affects the level of financial awareness among people. The findings of this current study concerning the age factor are in alignment with Che-Ha et al. (2017), Awan and Bukhari (2011), Ahmad et al. (2011), Loo (2010), Worthington (2006) and Dellande and Saporoschenko (2004).

The findings also indicate that the information about cryptocurrency is not symmetrically distributed among ethnic groups. The reasons for this could be many, and one of them has been underlined by Sabri et al. (2012). That is, the Malays are more influenced by religion in their daily lives including in financial matters compared to other ethnicities. Also, they are more brand loyal, less fashionoriented, and more peer-influenced. Our findings of the ethnicity factor are also in line with the findings by Che-Ha (2017), Haque (2010) and Haque et al. (2009) that ethnicity plays a significant role in choosing the financial services and products because of the level of financial awareness.

The results also show that occupational status does affect cryptocurrency awareness. This study found that respondents who are employed tend to be more aware of cryptocurrency than students and unemployed respondents. It has been well understood that employed people are more aware of advances in financial technology as they more exposed to those because of the nature of the employment itself. For example, employed people receive a salary, and the payment of the salary uses a bank as an intermediary. A bank offers many types of services, and employed people are given information about the services either by the bank itself or by another party, for example, the employer. Not only that, they are likely to receive promotions about other financial products such as insurance and investments, whether they are legal or not, from third parties. Also, financial awareness is more noticeable when the employment involves business. In other words, employed people learn about financial advances because of their work. This argument is in line with the findings from Che-Ha et al. (2017), Maruthu and Benjamin (2010), Bhushan and
Medury (2013), Shobana and Jayalakshmi (2010) and Chen and Volpe (1998).

From the respondents who have answered yes that they have heard about cryptocurrency, the study looked for significant differences concerning whether they had ever owned or used the cryptocurrency. The results determined that ethnicity and residency variables were significant in explaining whether a respondent either owned or used cryptocurrency. Residency plays a significant role in the usage of cryptocurrency as it correlates with business activities and payment services offered. Moreover, because business activities and payment services have a strong relationship with residency, cryptocurrency also has a strong relationship with residency as cryptocurrency interacts well with other payment methods in electronic commerce, which is part of business activities and payment services (Polasik et al., 2015). Notably, cryptocurrency includes not only Bitcoin but also Ripple, Ethereum or other cryptocurrencies or digital/electronic tokens that not only distributed via websites or exchanges but also via any other methods, including funfair tickets or digital tokens (Buterin, 2018). The differences in the more developed region such as West Coast Malaysia and other part of Malaysia such as East Malaysia and East Coast Malaysia may be due to the financial behaviour and attitudes not only between the respondents but also because of the services provided in those regions that affect the financial awareness and literacy as Morgan and Trinh (2019) found for Vietnam and Cambodia.

Lastly, the study found that all of the respondents preferred online payment methods other than cryptocurrencies, such as credit cards, debit cards, and PayPal. This preference also has significant differences based on gender, education, and occupation status. People who are used to one type of online payment method seem to be reluctant to change to a new online payment method, as Chen et al. (2017) and Polasik et al. (2015) suggested. This conclusion is in line with our findings. Also, the difference between gender can be described as males are found to be more adaptive than females when it comes to banking and financial products and services, as Nga et al. (2010) and Worthington (2006) suggested. For education and occupation status, Awan and Bukhari (2011) suggested that education makes people more selective based on their perception while occupation makes people more biased towards certain financial products (Bhushan and Medury, 2013; Henry et al., 2017). In conclusion, some people are aware and unaware of the existence of cryptocurrency, and the awareness significantly differs according to age, ethnicity, and occupation in Malaysia. Moreover, although people are aware of the existence of cryptocurrency, they remain reluctant to use cryptocurrency as an online payment method as they are more comfortable with other, more conventional methods.

These findings should be considered by regulators in Malaysia in formulating activities, policies, rules and regulations regarding cryptocurrency as cryptocurrency could be globally common in the near future as Buterin (2018), and Tsanidis et al. (2015) suggested so that the interests of Malaysian could be protected from any downsides of the cryptocurrency itself. 


\section{Doing Business using Cryptocurrency in Malaysia}

\section{REFERENCES}

1. Acquah-Sam, E. and Salami, K., 2013, Knowledge and participation in capital market activities: the Ghanaian experience. International Journal of Scientific Research in Education, 6 (2): 189-203

2. Aggarwal, S.K., Barua, S., Jacob, J. and Varma, J.R., 2012, A survey of financial literacy among students, young employees and the retired in India [online]. Available from: https://faculty.iima.ac.in/ iffm/literacy/youngemployessandretired201 2.pdf [Accessed 28 January 2018]

3. Ahmad, K., Rustam, G. A. and Dent, M.M., 2011, Brand preference in Islamic banking. Journal of Islamic Marketing, 2 (1): 74-82

4. Al-Ajmi, J., Abo Hussain, H., and Al-Saleh, N., 2009, Clients of conventional and Islamic banks in Bahrain. International Journal of Social Economics [online], 36 (11): 1086-1112. Available from: https://www.emeraldinsight.com/doi/10.1108/03068290910992642 [Accessed 28 June 2018]

5. Arango, C.A., Huynh, K.P., Fung, B.S.C., et al., 2012, The Changing Landscape for Retail Payments in Canada and the Implications for the Demand for Cash. Bank of Canada Review [online], 2012 (Autumn): 31-40. Available from: https://econpapers.repec.org/article/bcabcarev/v_3a2012_3ay_3a2012 _3ai_3aautumn12_3ap_3a31-40.htm [Accessed 28 June 2018]

6. Awan, H. and Shahzad Bukhari, K., 2011, Customer's criteria for Marketing, 2 (1): 14-27

7. Banumathy, K. and Azhagaiah, R., 2016, Investors' awareness about investment in stock market. Pacific Business Review, 8 (11): 14-22

8. Barber, B.M. and Odean, T., 1998, Boys will be Boys: Gender, Overconfidence, and Common Stock Investment. SSRN Electronic Journal [online]. Available from: http://www.ssrn.com/abstract=139415 [Accessed 2 May 2018]

9. Bernama, 2017, BNM To Enforce Crypto Regulation Next Year. Bernama Plus [online]. Available from:

10. Bernanke, B.S., 2011, Statement by Chairman Bernanke on financial literacy. [online], pp. 1-16. Available from: https://www.federalreserve.gov/newsevents/testimony/files/bernanke 20110420a.pdf

11. Bhattacharjee, J. and Singh, R., 2017, Awareness about equity investment among retail investors: a kaleidoscopic view. Qualitative

12. Bhushan, P. and Medury, Y., 2013, Gender differences in investment behaviour among employees. Asian Journal of Research in Business Economics and Management, 3 (12): 147-157

13. Blau, B.M., 2018, Price dynamics and speculative trading in Bitcoin. Research in International Business and Finance, 43: 15-21

14. Bouri, E., Jalkh, N., Molnár, P. and Roubaud, D., 2017, Bitcoin for energy commodities before and after the December 2013 crash: diversifier, hedge or safe haven? Applied Economics, 49 (50): 50635073

15. Boyd, W.L., Leonard, M. and White, C., 1994, Customer Preferences Marketing [online], 12 (1): 9-15. Available from: https://www.emeraldinsight.com/doi/10.1108/02652329410049562 [Accessed 22 May 2018]

16. Bucher-Koenen, T. and Lusardi, A., 2011, Financial Literacy and retirement planning in Germany. CeRP Working Papers, Centre for Research on Pension and Welfare Policies, Turin

17. Bumcrot, C.B., Lin, J. and Lusardi, A., 2013, The Geography of Financial Literacy. Numeracy, 6 (2): 1-16.

18. Buterin, V., 2016, A Next-generation Smart Contract and Decentralized Application Platform [online]. Available from: https://github.com/ethereum/wiki/wiki/White-Paper [Accessed 21 January 2019]

19. Chen, H. and Volpe, R.P., 1998, An analysis of personal financial literacy among college students. Financial Services Review [online], 7 (2): 107-128. Available from: https://www.sciencedirect.com/science/article/pii/S105708109980006 7 [Accessed 5 January 2018]

20. Chen, H. and Volpe, R.P., 2002, Gender Differences in Personal Financial Literacy Among College Students. Financial Services Review, 11 (3): 289-307

21. Chen, H., Felt, M.-H. and Huynh, K.P., 2017, Retail payment innovations and cash usage: accounting for attrition by using refreshment samples. Journal of the Royal Statistical Society: Series A (Statistics in Society) [online], 180 (2): 503-530. Available from: http://doi.wiley.com/10.1111/rssa.12208 [[Accessed 5 January 2018]

22. Clark, R.L., d'Ambrosio, M.B., McDermed, A.A. and Sawant, K., 2006, Retirement plans and saving decisions: the role of information selecting an Islamic bank: evidence from Pakistan. Journal of Islamic http://plus.bernama.com/v1/news2.php?id=1412883 Research in Financial Markets, 9 (4): 310-324 for Financial Services: An Analysis. International Journal of Bank

and education. Journal of Pension Economics and Finance [online], 5 (1): 45-67. Available from: https://www.cambridge.org/core/product/identifier/S14747472050022 71/type/journal_article [[Accessed 5 January 2018]

23. Clercq, B., 2009, Do our children know anything about money? An exploratory study. Meditari Accountancy Research [online], 17 (1): 1-13. Available from: http://www.emeraldinsight.com/doi/10.1108/10222529200900001 [[Accessed 5 January 2018]

24. Dale, L. and Bevill, S., 2007, An Analysis of the Current Status of Student Debt: Implications for Helping Vulnerable Students Manage Debt. Academy of Educational Leadership Journal [online], 11 (2). Available from: https://www.questia.com/library/journal/1G1175110718/an-analysis-of-the-current-status-of-student-debt [[Accessed 5 January 2018]

25. Dellande, S. and Saporoschenko, A., 2004, Factors in gaining compliance toward an acceptable level of personal unsecured debt. International Journal of Bank Marketing [online], 22 (4): 279-290. Available https://www.emeraldinsight.com/doi/10.1108/02652320410542554 [[Accessed 5 January 2018]

26. Finke, M.S., Howe, J.S. and and Huston, S.J., 2017, Old Age and the Decline in Financial Literacy. Management Science [online], 63 (1): 213-230. Available from: http://pubsonline.informs.org/doi/10.1287/mnsc.2015.2293 [Accessed 21 January 2019]

27. Frączek, B., 2014, Main Purposes and Challenges in the Financial Education of Financial Consumers in the World. Journal of Economics \& Management [online], 16: 27-43. Available from: http://cejsh.icm.edu.pl/cejsh/element/bwmeta1.element.desklight82562d42-b82f-48b0-a5a1-49d96e3bb47c [Accessed 21 January 2019]

28. Fung B., Huynh K.P. and Stuber, G., 2015, The Use of Cash in Canada. Bank of Canada Review, 2015 (Spring): 45-56

29. Glaser, F., Zimmermann, K., Haferkorn, M., Weber, M. and Siering, M., 2014, Bitcoin - Asset or currency? Revealing users' hidden intentions. In ECIS 2014 Proceedings - 22nd European Conference on Information Systems. 2014. pp. 1-14

30. Haque, A., 2010, Islamic banking in Malaysia: A study of attitudina differences of Malaysian customers. European Journal of Economics, Finance and Administrative Sciences, 18 (2010): 7-18

31. Haque, A., Jamil, O. and Zaki Hj Ismail, A., 2009, Factor Influences Selection of Islamic Banking: A Study on Malaysian Customer Preferences. American Journal of Applied Sciences [online], 6 (5): 922-928. Available from: http://www.thescipub.com/abstract/10.3844/ajassp.2009.922.928 [Accessed 21 January 2019]

32. Hayes, A.S., 2017, Cryptocurrency value formation: An empirical study leading to a cost of production model for valuing bitcoin. Telematics and Informatics, 34 (7): 1308-1321

33. Henry, C.S., Huynh, K. and Nicholls, G., 2018, Bitcoin Awareness and Usage in Canada: An Update [online]. Bank of Canada. Available from: https://www.bankofcanada.ca/2018/07/staffanalytical-note-2018-23/ [Accessed 28 July 2018]

34. Hoffman, M. J. R., McKenzie, S.M. and Paris, S., 2008, Paper or Plastic: CPAs Can Educate College Students on Responsible Credit Card Use. The CPA Journal, 2008 (September): 16-20

35. Jariah, M., Husna, S., Tengku Aizan, T .A. H., and Rahimah, I., 2012 Financial practices and problems amongst elderly in Malaysia. Pertanika Journal of Social Sciences \& Humanities [online], 20 (4): 1065-1084. Available from: http://www.myjurnal.my/public/articleview.php?id=74463 [Accessed 21 January 2019]

36. Jeyaram, S. and Mustapha, M., 2015, Financial literacy and demographic factors. Financial literacy and demographic factors, 2 (1): $1-8$

37. Joo, S. and Grable, J.E., 2004, An Exploratory Framework of the Determinants of Financial Satisfaction. Journal of Family and Economic Issues [online], 25 (1): 25-50. Available from: http://link.springer.com/10.1023/B:JEEI.0000016722.37994.9f [Accessed 21 January 2019]

38. Khattak, N.Z. and Rehman, K.U., 2010, Customer satisfaction and awareness of Islamic banking system in Pakistan. African journal of business management [online], 4 (5): 662-671. Available from: https://www.researchgate.net/publication/289204447_Customer_satis faction_and_awareness_of_Islamic_banking_system_in_Pakistan [Accessed 21 January 2019]

Published By:

Blue Eyes Intelligence Engineering \& Sciences Publication 
39. Kimiyaghalam, F., and Yap, S., 2017, Level of Financial Literacy in Malaysia. International Journal of Research [online], 4 (7): 10651074. Available

from: https://www.researchgate.net/publication/317646867_Level_of_Finan cial_Literacy_in_Malaysia [Accessed 21 January 2019]

40. Klapper, L.F. and Panos, G.A., 2011, Financial Literacy and Retirement Planning: The Russian Case. SSRN Electronic Journal [online]. Available from: http://www.ssrn.com/abstract=1984059 [Accessed 21 January 2019]

41. Loke, Y.J., 2017, The Influence of Socio-Demographic and Financial Knowledge Factors on Financial Management Practices of Malaysians. International Journal of Business and Society [online] 18 (1): 33-50. Available from: http://www.ijbs.unimas.my/index.php/content-abstract/all-issues/49vol-18-no-1-2017/311-the-influence-of-socio-demographic-andfinancial-knowledge-factors-on-financial-management-practices-ofmalaysians [Accessed 21 January 2019]

42. Loo, M., 2010, Attitudes and perceptions towards Islamic banking among Muslims and non-Muslims in Malaysia: Implications for marketing to baby boomers and $x$-generation. International Journal of Arts and Sciences, 3 (13): 453-485

43. Lusardi, A. and Mitchell, O., 2011, Financial literacy around the world: an overview. CeRP Working Papers, Centre for Research on Pension and Welfare Policies, Turin

44. Marriott, P., 2007, An Analysis of First Experience Students Financial Awareness and Attitude to Debt in a Post-1992 UK University. Higher Education Quarterly [online], 61 (4): 498-519. Available from: http://doi.wiley.com/10.1111/j.14682273.2007.00369.x [Accessed 21 January 2019]

45. Maruthu, P.P. and Benjamin, C.S., 2010, A study on equity investors awareness. PhD Thesis, Bharathia University, Tamil Nadu

46. Morgan, P.J. and Trinh, L.Q., 2019, Determinants and Impacts of Financial Literacy in Cambodia and Viet Nam. Journal of Risk and Financial Management [online], 12 (1): 19. Available from: http://www.mdpi.com/1911-8074/12/1/19 [Accessed 28 June 2019]

47. Nakamoto, S., 2008, Bitcoin: A Peer-to-Peer Electronic Cash System [online]. Available from: https://bitcoin.org/bitcoin.pdf

48. Nga, J.K.H., Yong, L.H. l. and Sellappan, R.D., 2010, A study of financial awareness among youths. Young Consumers, 11 (4): $277-$ 290

49. OECD, 2005, Improving Financial Literacy: Analysis of Issues and Policies. Paris

50. OECD, 2016, OECD/INFE International Survey of Adult Financial Literacy Competencies. Paris

51. Perry, V.G., 2008, Is Ignorance Bliss? Consumer Accuracy in Judgments about Credit Ratings. Journal of Consumer Affairs [online], 42 (2): 189-205. Available from: http://doi.wiley.com/10.1111/j.1745-6606.2008.00104.x [Accessed 28 June 2019]

52. Polasik, M., Piotrowska, A., Wisniewski, T., Kotkowski, R. and Lightfoot, G., 2014, Price Fluctuations and the Use of Bitcoin: An Empirical Inquiry. SSRN Electronic Journal [online]. Available from: http://www.ssrn.com/abstract=2516754 [Accessed 21 January 2019]

53. Rashid, M. and Hassan, M.K., 2009, Customer Demographics Affecting Bank Selection Criteria, Preference, and Market Segmentation: Study on Domestic Islamic Banks in Bangladesh. International Journal of Business and Management [online], 4 (6) p131. Available from: http://www.ccsenet.org/journal/index.php/ijbm/article/view/2330 [Accessed 21 January 2019]

54. Sabri, M.F., Cook, C. and Gudmunson, C., 2012, Financia well-being of Malaysian college students. Asian Education and Development Studies, 1 (2): 153-170

55. Schuh, S. and Shy, O., 2016, U.S. Consumers' Adoption and Use of Bitcoin and Other Virtual Currencies. Mimeo

56. Securities Commission Malaysia, 2019, Guidelines on Recognized Markets. [online]. Available from: https://www.sc.com.my/api/documentms/download.ashx?id=eb8f1b0 4-d744-4f9a-a6b6-ff8f6fee8701 [Accessed 21 June 2019]

57. Shobana, V.K. and Jayalakshmi, J., 2010, Investors awareness and performance. Organisational Management, 22 (3): 16-18

58. Shobha, T.S. and Shalini, S., 2015, A study on the perception of women towards financial planning in the city of Bengaluru. Asia Pacific Journal of Research, 1 (30): 14-21

59. Thambiah, S., Cyril Eze, U., Santhapparaj, A.J. and Arumugam, K., 2010, Customers' Perception on Islamic Retail Banking: A Comparative Analysis between the Urban and Rural Regions of Malaysia. International Journal of Business and Management [online], 6 (1): $\quad$ p187. Available from:

http://www.ccsenet.org/journal/index.php/ijbm/article/view/7484

[Accessed 21 January 2019]

Thilakam, C., 2012, Financial literacy among rural masses in India. Phuket

61. Tsanidis, C., Nerantzaki, D. M., Karavasilis, G., Vrana, V. and Paschaloudis, D., 2015, Greek consumers and the use of Bitcoin. The Business \& Management Review, 6 (2): 295-302

62. Urquhart, A., 2017, Price clustering in Bitcoin. Economics Letters, 159 (2017): 145-148 28 June 2019]

4. Worthington, A.C., 2006, Predicting financial literacy in Australia. Financial Services Review, 15 (1): 59-79.

Yussof, S.A. and Al-Harthy, A., 2018, Cryptocurrency as an Alternative Currency in Malaysia: Issues and Challenges. Islam and Civilisational Renewal, 9 (1): 48-65

\section{AUTHORS PROFILE}

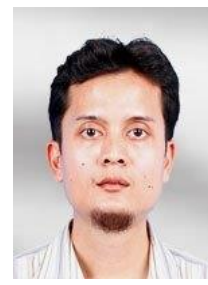

Dr. Ahmad Shauqi Haji Mohamad Zubir, PhD (Birmingham), MSc Quantitative Sc. (Fin Eng) (UiTM), BSc (Hons) Act. Sc. (UKM) Lecturer Email: shauqi@umt.edu.my | Phone: +609 6683794 Dr. Ahmad Shauqi Bin Haji Mohamad Zubir is finance lecturer at the School of Business and Maritime Management, Universiti Malaysia Terengganu (UMT), with more than 10 years teaching experience in the field. He holds a $\mathrm{PhD}$ in finance from the University of Birmingham. He was an affiliate of Registered Financia the role as a lecturer at UMT. His main research interest includes mathematical and econometrical modelling in finance, profitability analysis of financial assets and transactions, practicality of Islamic economics and finance, and investment evaluation and analysis.

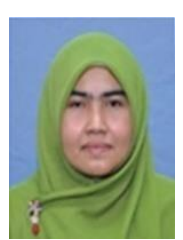

Dr. Nur Aishah Awi, PhD (Coventry), MSc, BSc (Hons), Diploma (UiTM) Lecture Email: nuraishah@umt.edu.my | Phone: +609 6684151

Dr. Nur Aishah is a lecturer of Management (Marketing) programme at the School of Maritime Business and Management, Universiti Malaysia Terengganu. She holds a $\mathrm{PhD}$ in Strategy and Applied Management from Coventry University, United Kingdom. She taugh Operation Management and Management Principle. Her current research interests includes operation management, lean management and quality management.

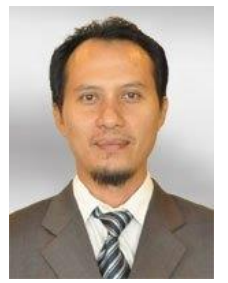

Dr. Azwadi Ali, PhD (Victoria), MAcc (UiTM), BA (Hons) Acc \& Fin (Lancaster) Associate Professor | Chairman of the Bachelor of Accounting Programme Email: azwadi@umt.edu.my | Phone: +609 6683449Dr. Azwadi Ali is an associate professor at the School of Maritime Business and Management, Universiti Malaysia Terengganu. He holds a Bachelor of Accounting and Finance from Lancaster University (UK), a master's degree in Accountancy from UiTM, and a Ph.D. from Victoria University (Australia). He has taught mainly Accounting Information Systems and finance-related subjects at the school for more than ten years. His research interests include personal finance and accounting information systems (user perspective). He has published his research works in a number of journals and has been appointed as graduate thesis examiner, both inside and outside UMT. 
Doing Business using Cryptocurrency in Malaysia

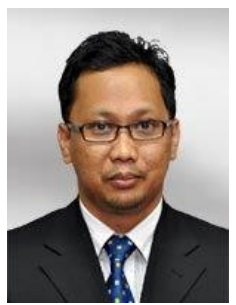

Dr. Safiek Mokhlis, MCIM, MIMM PhD (Stirling), MSc (UPM), BBA (UPM)

Associate Professor

Email: safiek@umt.edu.my | Phone: +609 6684188 / 4823

Dr. Safiek Mokhlis obtained his BBA and MSc degrees from Universiti Putra Malaysia, and a PhD from the University of Stirling, Scotland. He is a member of the Chartered Institute of Marketing (UK) and the Institute of Marketing Malaysia. He started his academic career in 2001 as Tutor, appointed as Lecturer in 2006, as Senior Lecturer in 2009, and as Associate Professor in 2013. He has taught a wide range of marketing courses at undergraduate level, including Retailing Management, Consumer Behavior, Marketing Research, Services Marketing, Product Management, and Channel Management. His research interests lie in the field of marketing, particularly consumer behavior. Specific interests include cultural influences on consumer behavior, consumer socialization, shopping orientation, retail patronage and service quality. He has published over 50 journal articles in these areas.

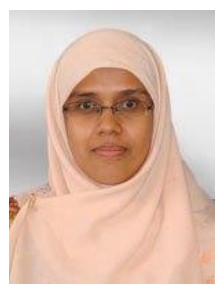

Dr. Farizah Sulong, ACCA, CA (M) PhD (IIUM) M. Com \& Admin (Acc) (Wellington), B.Com \& Mgt (Lincoln) Lecturer Email: arizah.sulong@umt.edu.my

Dr. Farizah Sulong is a Tutor under the School of Maritime Business and Management, Universiti Malaysia Terengganu. She holds a PhD from International Islamic University Malaysia, Bachelor of Commerce and Management Degree from Lincoln University, New Zealand and Masters of Commerce and Administration (Accountancy) Degree from Victoria University of Wellington, New Zealand. She is also a Chartered Accountant registered with the Malaysian Institute of Accountants (MIA) and Association of Chartered Certified Accountants (ACCA). Her research interests include environmental management accounting, sustainability accounting and management accounting.

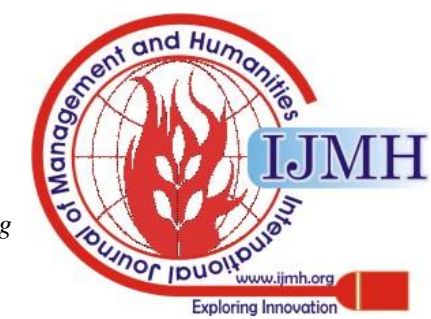

